\title{
Comment
}

\section{Technology and strategy in nuclear deterrence}

In his commentary on reducing risks in complex systems, Sonntag raises a number of interesting questions, especially for the military and weapon systems sector. Let me respond to, and expand upon, just a few of the very reasonable warnings that he outlines, especially that "we should look at the nuclear arms race far more critically than at most other hazards". We are indebted to him for the reminder that "the command and control system may not function as it should in a combat situation". One of the great dangers in the current strategic doctrine of both the US and USSR is the belief that nuclear war can be fought, controlled, limited - and won. This doctrine rests

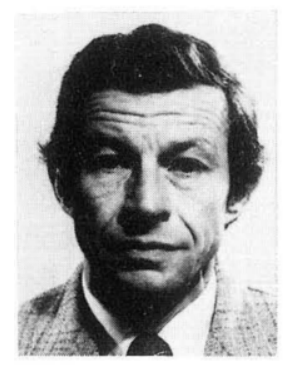

J. David Singer received his B.A. from Duke University, and his doctorate from New York University. He is currently Professor in the Political Science Department at the University of Michigan, having been Coordinator of the World Politics Program from 1969-1975. He has previously held teaching positions at New York University, Vassar College, and Harvard, and been a Visiting Faculty Member at the University of Oslo and Institute for Social Research, Norway; the Carnegie Endowment for International Peace and Graduate Institute of International Studies, Geneva, Switzerland; and ZUMA and the University of Mannheim, West Germany. His most recent books are Correlates of War I: Research Origins and Rationale, a Free Press anthology of his papers on the science-policy relationship and Correlates of War II: Testing Some Realpolitik Models, also a Free Press anthology with papers which apply theoretical propositions to real world data. Other books are The Study of International Politics: A Guide to the Sources for the Student, Teacher, and Researcher (with Dorothy LaBarr) (1976); Beyond Conjecture in International Politics: Abstracts of Data-Based Research (with Susan Jones) (1972); The Wages of War, 1816-1965: A Statistical Handbook (with Melvin Small) (1972); Deterrence, Arms Control, and Disarmament: Toward a Synthesis in National Security Policy (1962); Financing International Organization: The United Nations Budget Process (1961); as well as numerous articles in such journals as American Political Science Review, International Security, British Journal of International Studies and Journal of Conflict Resolution.

North-Holland Publishing Company

Human Systems Management 3 (1982) 4-5 heavily on the dubious assumption that current command and control arrangements would permit such limitation, and on the even more dubious assumption that they would do so in the context of a European or inter-continental nuclear exchange.

There is, of course, another fundamental flaw in the super powers' drive for damage-limiting, warfighting, silo-busting, flexible nuclear forces. Even if the Soviets and the Americans intend to use these counter-force weapon systems only if nuclear war "breaks out", they will appreciably increase the probability of such an event. To develop and deploy a weapons technology that may be useful in the event of war is to misuse the concept of insurance, if that deployment affects the probability of the undesired event. That is, these war-fighting nuclear weapons are virtually identical to those one would need to launch - or threaten to launch - a pre-emptive first strike. They are accurate, powerful and numerous enough to threaten seriously the adversary's retaliatory forces, and they are vulnerable enough to have very little retaliatory value for their owners. To put it another way, both sides are moving toward a weapons technology whose vulnerability and lethality reduce their deterrent effects while increasing their provocative effects. This makes for a set of man-machine systems with an unacceptably low deterrence-to-provocation ratio.

The solution, it would seem, lies in recognizing the technological infeasibility of either side's acquiring a truly credible first-strike force, and the fragility and unreliability of an intra-war command and control system that would permit a controlled and limited nuclear exchange. Out of this recognition should come the acceptance of a "minimal" or "finite" strategic deterrent and the resulting increase in the stability of the stand-off. As to specific moves, both sides should immediately halt any further production or deployment of the more accurate and more vulnerable land-based nuclear weapons, and actually begin to phase out all remaining land-based missile systems. This would help signal that leaders have accepted the 
"no first use" principle, and thus reduce - as Sonntag has noted - the dangerous need to "launch on warning".

There is, of course, much more to the problem than this, but clearly the first step is to back away from the acquisition of a weapons technology that enhances no nation's security and jeopardizes that of almost all nations. As students of human systems and their management, we could have no higher priority than addressing the dangers of nuclear war.

J. David SINGER 